\title{
$\underbrace{6}_{\text {IJPBA }}$
}

Contents lists available at www.ijpba.in

International Journal of Pharmaceutical and Biological Science Archive

NLM (National Library of Medicine ID: 101738825)

Index Copernicus Value 2019: 71.05

Volume 9 Issue 1; January-February; 2021; Page No. 07-15

\section{PHYSICOCHEMICAL STUDY AND QUANTITATIVE ANALYSIS SWARNA MAKSHIKA BHASMA.}

\author{
Rajni Bhardwaj ${ }^{1}$, Smita Johar ${ }^{2}$, Amit Kapila ${ }^{3}$, Amandeep Sharma ${ }^{4}$ \\ ${ }^{1}$ Assistant Professor, Department of Rasashastra \& Bhaishajya Kalpana. Desh Bhagat Ayurvedic College \& Hospital \\ Desh Bhagat University, Mandi Gobindgarh (Punjab). \\ ${ }^{2}$ Professor and H.O.D, Department of Rasashastra, Desh Bhagat Ayurvedic College \& Hospital, Mandi Gobindgarh, \\ Punjab. \\ ${ }^{3}$ Assistant Professor, Department of Rasashastra \& Bhaishajya Kalpana, Desh Bhagat Ayurvedic College \& Hospital, \\ Mandi Gobindgarh, Punjab. \\ ${ }^{4}$ Assistant Professor, Department of Agad Tantra, Desh Bhagat Ayurvedic College \& Hospital, Mandi Gobindgarh, \\ Punjab.
}

\author{
Conflicts of Interest: Nil
}

Corresponding author: Rajni Bhardwaj

DOI https://doi.org/10.32553/ijpba.v9i1.172

\begin{abstract}
Swarnamakshika is grouped under Updhatu of Swarna and is composed of Copper, Iron and Sulphur. In this study Swarnamakshika was subjected to Shodhana by Bharjana with Nimbuka swarasa and Shudha Swarnamakshika was given Bhavana with Nimbuka swarasa and subjected to Varahaputa. With ten Varahaputa Bhasma Siddhi Lakshanas were attained swarnamakshika Marana was done by using Nimbuka swarasa until bhasma siddi lakshanas found and it took 10 puta till it attained reddish brown color. The X-ray diffraction analysis showed that d-identified peaks after 10th puta Swarnamakshika bhasma composition is of Iron oxide with rhombohedral crystal system as main component. EDX analysis of Swarna makshika bhasma shows that it contains Iron and Oxygen, as major element and Copper, Sulphur, Carbon, Aluminium, Calcium etc. as minor elements. FESEM study revealed that the particle size of Ashudha and Shudha Swarnamakshika was in the range of $500 \mathrm{~nm}-3 \mathrm{~nm}$.
\end{abstract}

Keywords: Swarnamakshika Bhasma, Nimbuka swarasa, puta

\section{INTRODUCTION}

Bhasmas are biologically produced nanoparticles, which are prescribed in a lower dose but act even on the smallest body channels (Strotas) and penetrate into the deepest tissues to give desired results. ${ }^{l}$ In the present scenario the tradition of making medicines by the practitioners have almost come to an end. Presently many Pharmaceutical industries are preparing classical medicines but have lost their credibility due to increased demand, poor manufacturing practices and not following proper guidelines in order to gain profits. So, preparation of Ayurvedic medicines need immediate and extensive orientation in order to provide quality medicine. Swarnamakshika is a Updhatu of gold and is composed of Copper, Iron and Sulphur. Swarnamakshika is used Rasayana drug and is indicated in diseases like Pandu, Anidra, Apasmara etc. ${ }^{2}$ A standard Swarnamakshika is prepared conveniently by using Nimbuka swarasa as
Shodhana and Marana media and samples were subjected to analytical study. Present study was carried out in the Rasashastra and Bhaishajya Kalpana Department Laboratory of Desh Bhagat Ayurvedic College and Hospital, Mandi Gobindgarh, with the prime objective of preparing safe, effective and quality sample of Swarnamakshika bhasma.

\section{Material and Methods:}

This study was carried in the following steps:

- Collection and selection of the raw material

- Shodhana of Swarnamakshika

- Marana of the Swarnamakshika

1. Collection and selection of the raw material

Ashudha Swarnamakshika was collected from Sri Herbacia Biotech, Amritsar, having all grahaya lakshanas as told in classcics. The raw material was authenticated from Government drug testing laboratory, Patiala. 


\section{SHODHANA OF SWARNAMAKSHIKA ${ }^{3}$}

Total weight of Swarnamakshika sample 750 grams was taken. After Crushing with iron mortar and pestle, 50 grams of the sample was given for authentication of the raw material.

Duration: 3 Days

\section{Ingredients}

- Major raw material

- Associated raw material

- Yantras

Major raw material: The major raw material of the present study is Swarnamashika.

Associated raw material: The associated raw material for the present study is Nimbuka ( citrus acida).

Yantras: Khalva Yantra and Puta Yantra were used in the present study. Steel vessel, iron frying pan (Loha kadahi) weighing machine, iron ladle, charcoal furnace heating device, wooden rod, knife, juice extractor, thread, mulmul cloth, multani mitti, spoon etc.

Main procedure:

- Bharjana of Swarnamakshika

Material: Swarnamakshika churna -- 700gms

Nimbuka Swarasa -- 1500ml

Procedure: Out of large number of processing techniques for Shodhana described in Rasa literature, roasting (Bharjana) technique with frequently addition of lemon juice described in Rasa Tarangini.

a) Fine powder of Swarnamakshika was made with the help of iron mortar and pestle

b) Powderd Swarnamakshika was taken in a clean and dry iron pan and heated on the charcoal furnace

c) Intense heat at about the temperature of $8500 \mathrm{C}$ to $900 o C$ was given with frequent addition of lemon juice. Continuous stirring was done with the help of small darvi throughout the process.

d) When the lemon juice was added during the process, iron pan was covered with iron plate to avoid the loss of raw material due to heavy dusting.

e) The process was continued till cessation of sulphur fumes.

f) Repeated the same procedure for 3 days at least 4 hours per day.

g) Heating was stopped when the bottom of the iron vessel attained red colour.

Observations:

a) Fumes of sulphur odour were continously observed after heating, upto 50 minutes.

b) During the addition of lemon juice to the heating iron pan containing

c) Swarnamakshika, a heavy dusting of the material was observed.

d) Colour of powdered Swarnamakshika changed from light greenish to dark greenish and mixture became paste like.

e) Soon after bubbles started appearing in the mixture and the mixture became more liquid in nature than before.

f) After 25 to 30 minutes of heating, the mixture became sticky and attained semi solid state and the colour of the mixture was blackish grey.

g) In the next step, moisture content of the mixture was completely evaporated and the mixture turned to powder form and the colour changes to dark purple

h) With the coarse of time of heating, the colour of the mixture was turned into dark rust brown.

i) After completion of the process, the heating was stopped, when the bottom of the iron vessel attained red colour.

j) Total 3 days were taken for completion of Shodhana process.

\section{Precautions:}

a) Sufficient quantity of Nimbuka swarasa was taken for total immersion of the mixture.

b) Care was taken to avoid the spilling of the mixture from the iron vessel.

c) Care was taken to avoid the adherence of the mixture to the iron vessel.

Results: Weight of Swarnamakshika Churna before Shodhana - 700gms Weight of Swarnamakshika Churna after Shodhana - 630gms Loss of weight $70 \mathrm{gms}$

\section{MARANA OF SHUDDHA SWARNAMAKSHIKA ${ }^{4}$}

Material: Shuddha(Bharjita) Swarnamakshika-$625 \mathrm{gms}$ Nimbuka Swarasa -- $340 \mathrm{ml}$

Equipments: Two earthen saravas of equal size, khalwa yantra, mulmul cloth,multani mitti,Vanopalas $12 \quad 1 / 2 \quad \mathrm{~kg}$ (cowdung cake), camphor, weighing machine, pyrometer.

Principle: Wet Triturations \& Puta system of heating.

\section{Method:}

- Extaction of Nimbuka swarasa.

- Mixing of Shudha Swarnamakshika powder with extracted Nimbuka Swarasa.

- Bhavana with Nimbuka Swarasa.

- Preparation of Chakrikas.

- Sarava samputa formation.

- Subjecting to Varaha Puta.

Procedure:

a) Mxing of Shuddha Swarnamakshika with nimbuka swarasa

- $625 \mathrm{gms}$ of Shuddha Swarnamakshika was taken in Khalwa yantra. 
- It was triturated with $340 \mathrm{ml}$ of freshly prepared nimbuka swarasa for 7 hours

- Trituration was done until it attains a viscous, semisolid consistency.

This is very important step, needs care and skill for proper blending of material and further reduction of particle size takes place in consequent putas, which further shortens the time factor and reduces the fuel quantity by reducing frequency of firing, for proper and uniform mixing of the core and surface of the pellets.

b) Preparation of Chakrikas (Pelletization)

- After completion of bhavana process, small uniform and approximetly equal size pellets were prepared out of the paste.

- Chakrikas were prepared of size $4 \mathrm{~cm}$ diameter, $0.7 \mathrm{~cm}$ thickness.

- Weight of each chakrika 18-19 grams

- Chakrikas were kept for drying.

- If chakrikas will not dry properly then it will become hard after subjecting to heat,which are supposed to be soft otherwise

- Average weight of chakrika after drying was $625 \mathrm{gms}$.

Table No.1 Showing Observations of Chakrikas before subjecting to puta.

\begin{tabular}{|l|l|l|}
\hline S.No & Parameters & Observations \\
\hline 1 & Color & Rust brown \\
\hline 2 & Taste & Metallic \\
\hline 3 & Odour & Metallic with sulphur \\
\hline 4 & Touch & Hard \\
\hline 5 & Weight & 625 gms \\
\hline
\end{tabular}

\section{c) Sharava Samputa formation:}

- Two concave shaped earthen sharavas were taken with circumference $82 \mathrm{~cm}$ and diameter $25 \mathrm{~cm}$.

- Dried chakrikas were arranged properly inside the sharavas suitably to facilitate appropriate distribution of heat to all the chakrikas.This is an important step to have ideal bhasma with minimum frequency of puta.

- Another Sarava was placed over it to make samputa. Gap between two saravas was properly sealed with seven layers of rags and mud(kapadmitti) .Each layer was wrapped after drying of previous layer.

- If the joint is loosely sealed then there is chance of adulteration of ash of cowdung cake, After sealing the samputa, dry it completely under sunlight d) Varaha Puta:

Varaha puta was selected according to the Rasaratna samucchaya. Varaha puta was given by using the underground pit of following dimensions-Height 42 cm.sq (16 angula) ,Depth 42 cm.sq (16 angula),Width $42 \mathrm{~cm} . s q$ (16 angula). The $2 / 3$ part of the pit was filled with 64 cowdung cakes weighing $8 \mathrm{~kg}$ and sharava samputa

was placed over it.

- Thermocouple of the pyrometer was placed vertically from the side of the pit at the junction between lower 2/3rd and upper 1/3rd of the cowdung cakes.

- $\quad$ Remaining $1 / 3$ rd of the pit was filled with 36 cow dung cakes weighing $4 \frac{1}{2} \mathrm{kgs}$.

- To facilitate easy catching of the fire. camphor balls were placed on four corners of the puta and cow dung cakes were ignited and burning went slowly.

- The temperature was recorded on every 15 minutes

- The burning continued and samputa was left for swanga sheeta on the following day.

- On the next day the samputa was taken out of pit and opened cautiously and

- Swarnamakshika chakrikas was collected and weighed.

- This whole procedure was repeated for every puta.

\section{Observations:}

- Swarnamakshika chakrikas before subjecting to Puta were rust brown in color, shiny, weighing 625 gms in total.

- During the process of puta, there was smell of fumes of sulphur, which was reduced after time period of $45 \mathrm{~min}$.

- The maximum temperature recorded was $781^{\circ} \mathrm{C}$.

- Total time taken for burrning of cowdung cake was 6 hours and for complete self cooling 24 hours. 
- After sarava were made open carefully, the Swarnamakshika chakrikas were observed as dark brown in color.

- Chakrikas were hard and metallic sound was heard.

- Weight of chakrikas was reduced to $575 \mathrm{gms}$
- On pounding, they were easily powdered.

- The whole powder colour resembled dark brown.

- $\quad$ Procedure is repeated till $10^{\text {th }}$ puta

Table 2: Showing Lakshanas of Swarnamakshika Bhasma after 10th puta

\begin{tabular}{|l|l|}
\hline Parameters & Observations \\
\hline Colour & Reddish brown \\
\hline Taste & Tasteless \\
\hline Odour & Odourless \\
\hline Touch & Soft \\
\hline Lusture & Absent \\
\hline Appearance & Very fine powder \\
\hline Rekhapoornata & Positive \\
\hline Varitara & Positive \\
\hline
\end{tabular}

Result:-Weight of Chakrikas before 10th puta 411gms

\section{Quantitative analysis}

\section{$\mathrm{X}$ ray diffraction (XRD)}

$\mathrm{X}$ Ray Diffraction is an efficient analytical technique used to identify and characterize unknown crystalline material. Monochromatic X-rays are used to determine the interplanar spacing of the unknown materials .Sample are analysed as powders with grains in random orientation to ensure that all crystallographic directions are "sampled" by the beam .When the bragg's condition for constructive interference is obtained, "reflection" is produced and the relative peak height is generally proportional to the number of grains in a preferred orientation.

Principle Distance between each set of atomic planes (i.e inter atomic space "d") is determined with the help of wavelength of X-Ray beam and angle of diffraction theta by applying bragg's law $\mathrm{n} \lambda=2 \mathrm{~d} \sin \theta$ No two substances have absolutely identical diffraction patterns the "d" spacing of the ten most intense reflecting planes of atoms are calculated and results are compared with the data of X-Ray powder data file and identification of the sample is done.

Method Different methods available for x-ray diffraction are Lane photographic method, Bragg $\mathrm{x}$ ray spectrometer method, Rotating crystal method and powder method. In the present study powder method of diffraction has been adopted.

\section{Sample preparation}

The sample are ground to a fine homogeneous powder then placed in a sample holder or the specimen may be mixed with a suitable noncrystalline binder and moulded into a suitable shape. As a result large number of small crystallites are oriented in all possible direction and when x-ray beam traverses the material a significant number of particles are expected to be oriented in such a manner that Bragg's equation for reflection from every possible inter planar spacing becomes satisfied.

\section{Advantages}

- Rapid identification of materials

- Ease off sample preparation

- Computer aided material identification

- Larger library of known-crystalline structures Applications

- Characterizing the crystallographic structure and characterizing heterogeneous solid mixtures( such as our kupipakwa rasayanas and bhasmas).

- Determining relative abundance and actual state of chemical combination.

- Only method available for determining polymorphs of a substance. The effect of polymorphism on solubility is particularly important from pharmaceutical point of view.

- Differentiating among various oxides for e,g difference between $\mathrm{FeO}, \mathrm{Fe}_{2} \mathrm{O}_{3}$, and $\mathrm{Fe}_{3} \mathrm{O}_{4}$ can be identified.

\section{Field emission scanning electron microscopy with energy dispersive $x$-ray FESEM-EDS ${ }^{226}$}

Field emission scanning electron microscope is used to observe small structure (as small as one nanometre), A FESEM is a microscope that works with electrons (particles with a negative charge) instead of light, These electrons are liberated by a field emission source the object is scanned by electrons according to a zigzag pattern. The sample region evaluated with FESEM Analysis can also be 
analyzed to determine the specific elements that comprise the sample region by utilizing Energy Dispersion Spectroscopy (EDS). X-rays are also released from the surface of the sample that carry a unique energy signature that are specific to elements found in the sample. These X-rays are detected with the EDS detector to give elemental information about the sample. EDS provides data about the chemical composition of the sample and provides additional data about the features that are observed in the SEM micrographs. This combined technique is referred to as FESEM-EDS or FESEM-EDX Analysis.

Principle: A FESEM is used to visualise very small topographic details on the surface or entire or fraction object, Researchers in Biology, Chemistry and Physics apply this technique to observe structures that may be as small as 1 nanometer (= billion of a millimetre) The FESEM may be employed for example to study organelles and DNA material in cells, synthetic polymers and coatings on microchips. The microscope that has served as an example for the virtual FESEM is a Jeol 6330 that is coupled to a special freeze fracturing device.

Method: Electrons are liberated from a field emission source and accelerated in a high electrical field gradient. With in the high vacuum column so called primary electrons are focused and deflected by electronic lenses to produce a narrow scan beam that bombards the object. As a result secondary electrons are emitted from each spot on the object. The angle and velocity of these secondary electrons relates to the surface structure of the object.A detector catches the secondary electrons and produces an electronic signal this signal. This saignal is amplified and transformed to a video scan image that can be seen on a monitor or to a digital image that can be saved and processed further.

Sample preparation: Objects are first made conductive for current. This is done by coating them with an extremely thin layer (1.5 to 3.0nm) of gold Palladium. Further on, objects must be able to sustain the high vacuum and should not alter the vacuum, for example by losing water molecules or gasses. Metals, polymers and crystals are usually little problematic and keep their structure. Biological material, however requiress a pre fixation e.g with cold slush nitrogen (cryo-fixation or with chemical compounds. This particular microscope is for seen of a special cryo- unit where frozen objects can be protected and quoted for direct observation in the FESEM. Chemically fixed material needs first to be washed and dreid below the critical point to avoid damage of the fine structuresr due to surface tension. Coating is then performed in a separate device.

\section{Advantages}

- FESEM gives better resolution than SEM. because field emission source is used in FESEM.

- It can tolerate high electrostatic fields.

- FESEM at labs-Services is capable of performing high-resolution imaging with very low accelerating voltages.

\section{Applications}

- Ideal microscopic imaging for polymer and thin films.

- Fine corrosion evaluations.

- Micro-structure studies best suitable for R\&D.

- Detail specimen features characterization.

- Surface contamination elemental analysis.

- Material analysis for component layers.

\section{OBSERVATION AND RESULTS}

\section{X - Ray Diffraction Study}

The 2 - theta value and intensity of the peak (counts) are represented on $\mathrm{X}$ and $\mathrm{Y}$-axis respectively. Higher the value of counts, represents higher the crystallanity of the phase, for identification of each phase minimum 3 strong peak were chosen.

Table 3: Showing XRD report of ASM

\begin{tabular}{|l|l|l|l|}
\hline Peak No. & Angle 2 & d space & Intensity \\
\hline 4 & 33.079 & 2.705 & 100 \\
\hline 5 & 37.119 & 2.420 & 50.01 \\
\hline 9 & 56.310 & 1.632 & 57.02 \\
\hline
\end{tabular}


Table 4: Showing XRD report of SSM

\begin{tabular}{|l|l|l|l|}
\hline Peak No & Angle & d space & Intensity \\
\hline 2 & 33.176 & 2.698 & 100 \\
\hline 3 & 35.649 & 2.516 & 80.56 \\
\hline 6 & 54.086 & 1.694 & 37.16 \\
\hline
\end{tabular}

Table 5: Showing XRD report of SMB after $10^{\text {th }}$ puta

\begin{tabular}{|l|l|l|l|}
\hline Peak No & Angle & d space & Intensity \\
\hline 2 & 30.302 & 2.947 & 31.39 \\
\hline 3 & 33.208 & 2.695 & 63.83 \\
\hline 4 & 35.693 & 2.513 & 100 \\
\hline
\end{tabular}

\section{FESEM - EDX STUDY}

Table 6: Showing FESEM - EDX of SMB after $10^{\text {th }}$ puta

\begin{tabular}{|l|l|l|l|l|l|l|l|}
\hline \multirow{2}{*}{ Element } & \multicolumn{3}{l|}{$\mathbf{1}^{\text {st }}$ Reading } & \multicolumn{2}{l|}{$\mathbf{2}^{\text {nd }}$ Reading } & \multicolumn{2}{l|}{$\mathbf{r}^{\text {rd }}$ Reading } \\
\cline { 2 - 8 } Wt \% & At \% & Wt \% & At \% & Wt \% & At \% & \\
\hline $\mathrm{O}$ & 21.95 & 44.97 & 21.92 & 45.57 & 37.80 & 59.93 & 27.22 \\
\hline $\mathrm{C}$ & 4.00 & 10.92 & 3.29 & 9.11 & 0.54 & 1.14 & 2.61 \\
\hline $\mathrm{Zi}$ & 1.87 & 0.67 & 1.99 & 0.73 & 3.17 & 0.88 & 2.34 \\
\hline $\mathrm{Ca}$ & 1.55 & 1.27 & 1.57 & 1.30 & 6.36 & 4.02 & 3.16 \\
\hline $\mathrm{Si}$ & 0.49 & 0.57 & 0.51 & 0.61 & 20.23 & 18.28 & 7.08 \\
\hline $\mathrm{Al}$ & 0.39 & 0.47 & 0.42 & 0.51 & 0.62 & 0.58 & 0.477 \\
\hline $\mathrm{K}$ & 0.56 & 0.47 & 0.64 & 0.55 & 3.78 & 2.46 & 1.66 \\
\hline $\mathrm{S}$ & 0.25 & 0.25 & 0.28 & 0.29 & 0.10 & 0.08 & 0.63 \\
\hline $\mathrm{Zn}$ & 0.26 & 0.13 & - & - & 0.12 & 0.05 & 0.127 \\
\hline $\mathrm{P}$ & 0.00 & 0.00 & - & - & 0.00 & 0.00 & 0.00 \\
\hline $\mathrm{Na}$ & 0.00 & 0.00 & - & - & 0.37 & 0.40 & 0.123 \\
\hline $\mathrm{Ni}$ & 0.26 & 0.14 & - & - & 0.00 & 0.00 & 0.087 \\
\hline $\mathrm{Cu}$ & 0.33 & 0.17 & - & - & 0.68 & 0.27 & 0.337 \\
\hline $\mathrm{Fe}$ & 67.27 & 39.49 & 69.37 & 41.33 & 26.22 & 11.91 & 54.29 \\
\hline $\mathrm{Co}$ & 0.83 & 0.46 & - & - & 0.01 & 0.00 & 0.28 \\
\hline $\mathrm{Ag}$ & 0.00 & 0.00 & - & - & 0.00 & 0.00 & 0.00 \\
\hline
\end{tabular}

Graph 1: The graph showing the time and temp. during $1^{\text {st }}$ Varaha puta

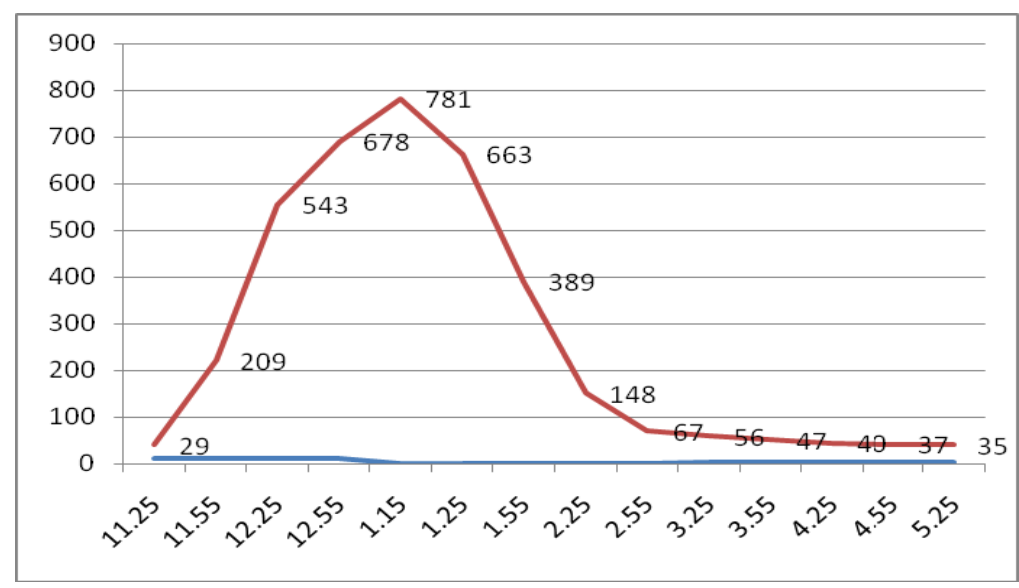


Graph 2: The graph showing the time and temp. during fifth Varaha puta

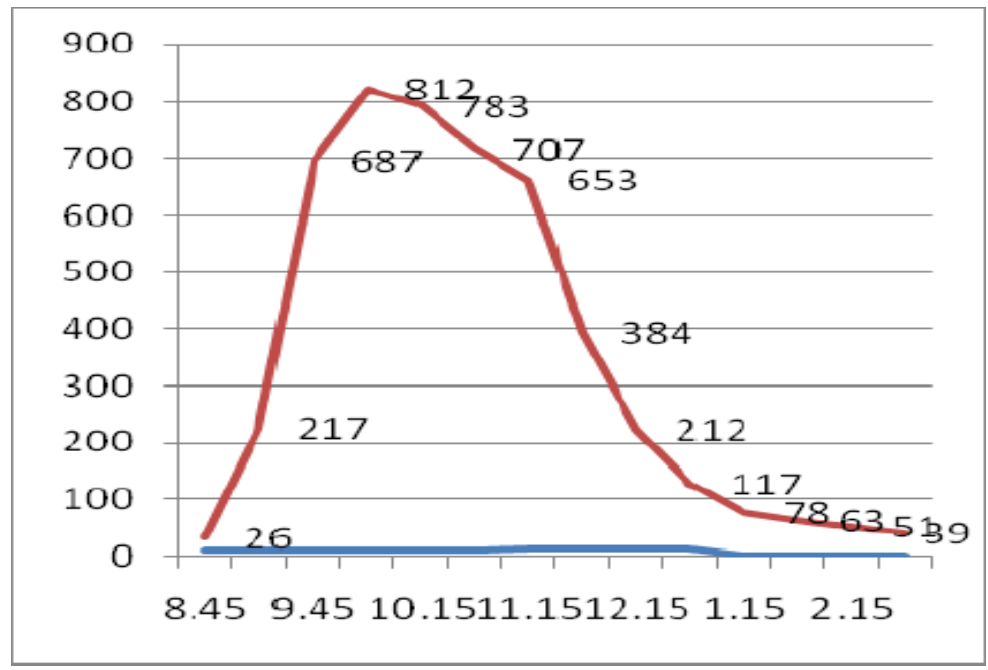

Graph 3: The graph showing the time and temp. during tenth Varaha puta

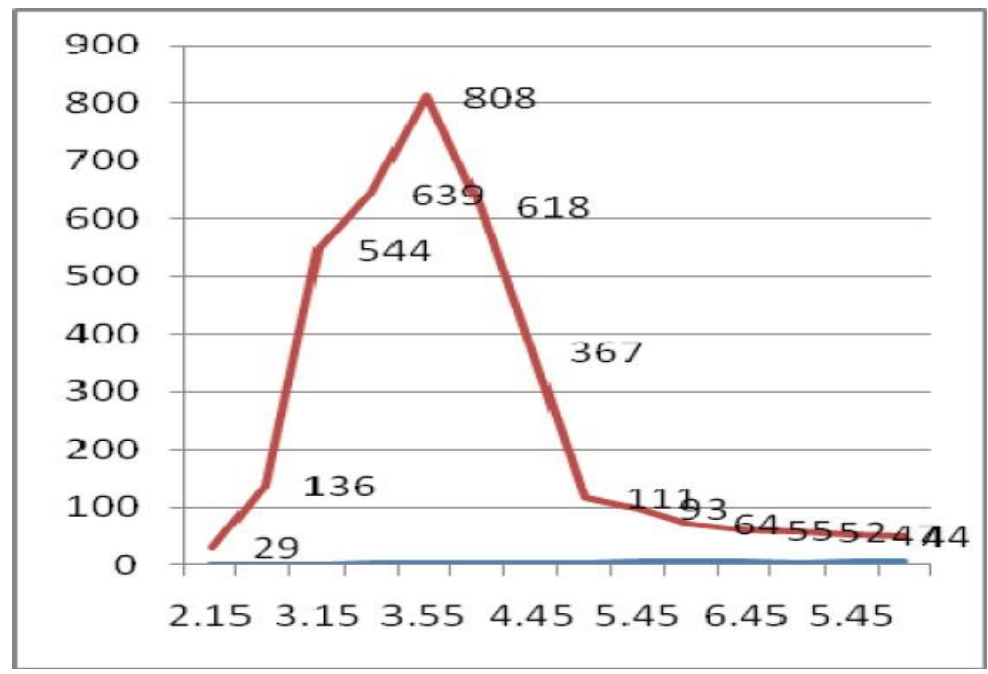

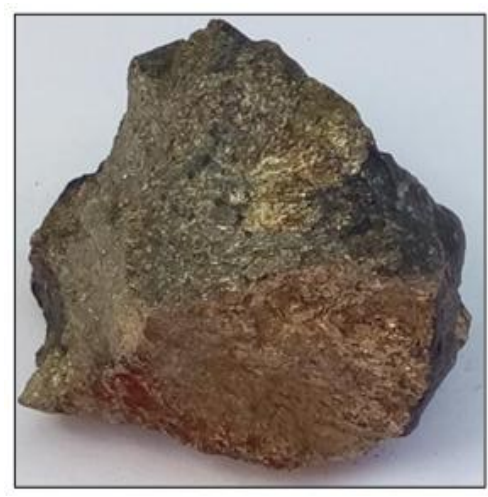

1. Raw Swaranamakshika

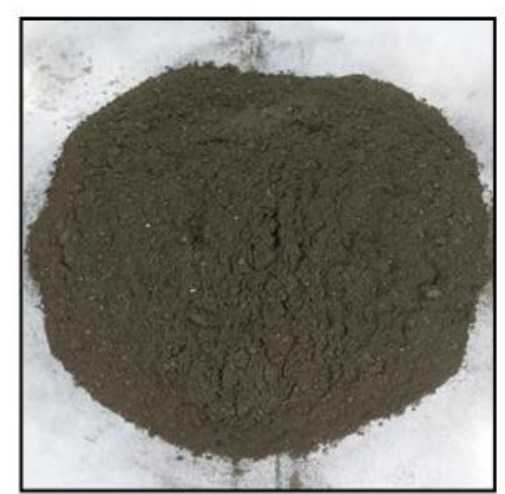

2. Ashudha Swaranamakshika powder

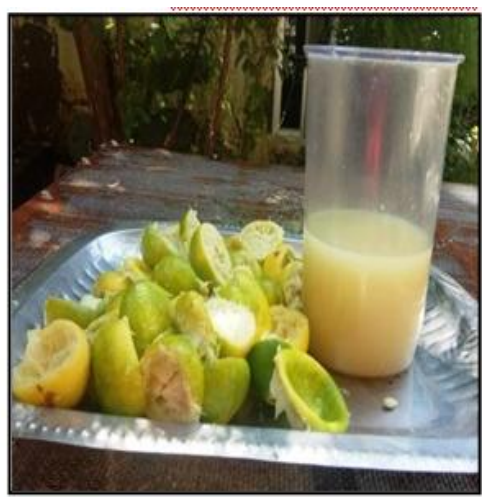

3. Nimbuka Swarasa 


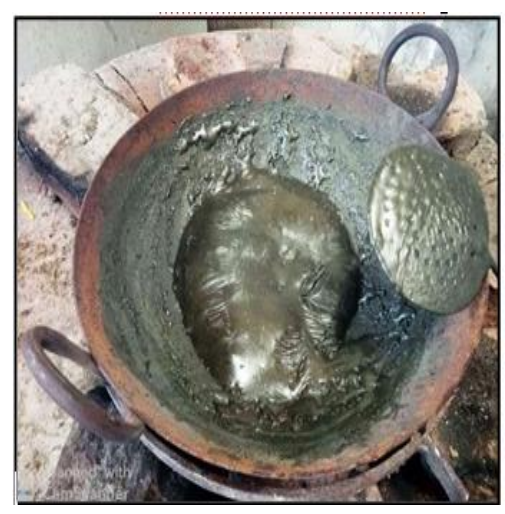

4.Makshika Bharjana (1)
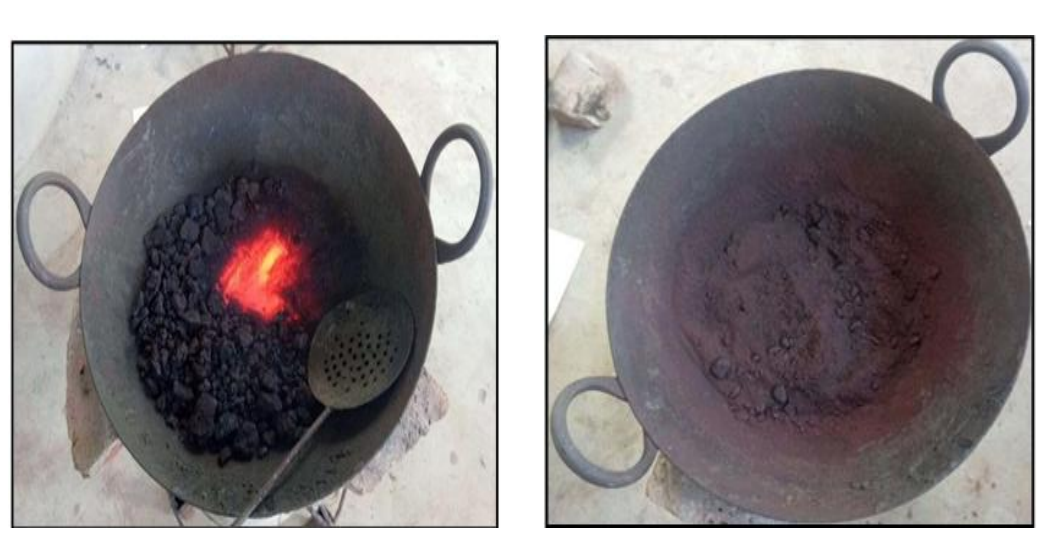

5.Makshika Bharjana

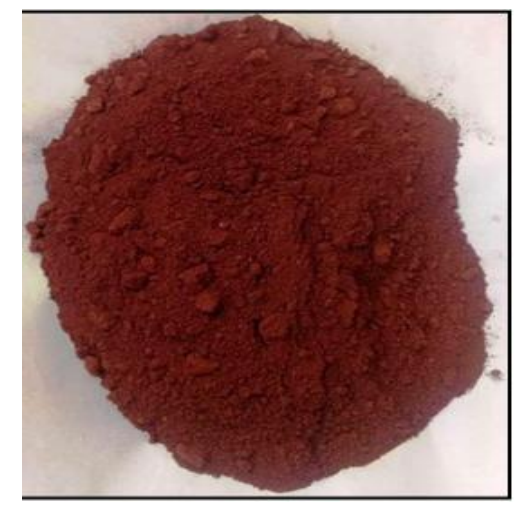

7. Shudha Makshika powder

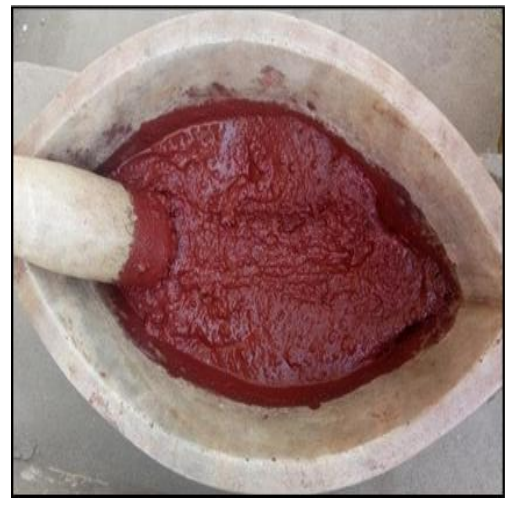

8. Nimbuka swarasa bhavana

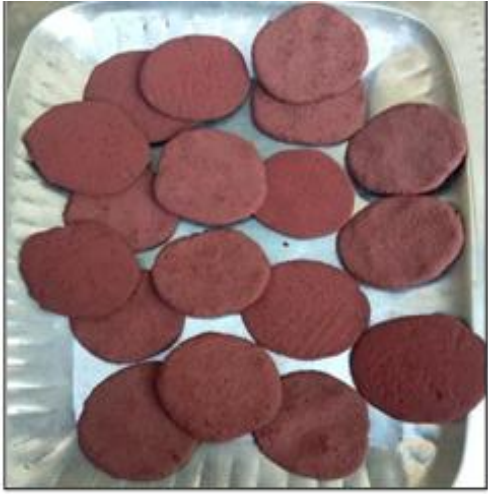

9 Chakrika

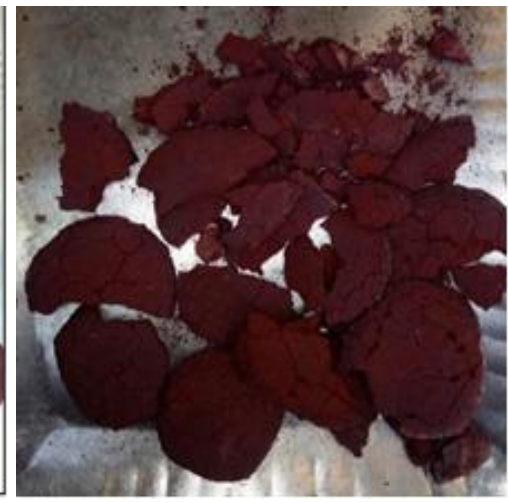

10 Chakrikas after $10^{\text {th }}$ puta

\section{Discussion}

X--Ray Diffraction ${ }^{5}$ : X--Ray Diffraction Studies were done with aim of determining structure and composition of the samples. Sample of Ashudh Swarnamakshika shows d-space value as follows 2.705, 2.420 and 1.632 having cubic crystal system when compared with JCPDF standards, compound identified as Copper Iron Sulphide CuFeS2. Sample of Shudha Swarnamakshika shows d-space value as follows 2.698, 2.516 and1.694 having cubic crystal system, when compared with JCPDF standards. Compounds identified as copper iron sulphide
(CuFeS2). Analytically Ashudh Swarnamakshika and Shuddha Swarnamakshika have similar chemical compound but they slightly differ in dspace values, where as remaining are almost same with minimum range value difference. ${ }^{6}$

Sample of Swarnamakshik bhasma after tenth puta shows the space values as follows $30.302,33.208$ and 35.693 having Rhombohedral crystal system when compared with JCPDF standards, compound identified as Iron oxide (Fe2O3). It is assumed that oxidation in subsequent putas has resulted in more oxide formation and decomposition of $\mathrm{CuFeS} 2$ into $\mathrm{Fe} 2 \mathrm{O} 3$ which is also evident by identification of 
more peaks of iron oxide. Many small peaks are also there that indicates that different compounds are also present in the bhasma in trace amount. Thus, it could be stated that the amount of heat and duration of heat in form of putas has caused the increase in oxidation.

FESEM-EDX ${ }^{7}$ : FESEM-EDX study reveals accurate elemental analysis of the sample.This study of elements enable us to explore major, minor and trace elements.The detected elements of Swarnamakshika bhama after tenth puta are as follows $\mathrm{Cu}(0.337), \mathrm{Fe}(54.29), \quad \mathrm{S}(0.63), \mathrm{O}(27.22)$, $\mathrm{C}(2.61), \mathrm{Zi}(2.34), \mathrm{Ca}(3.16), \mathrm{Si}(7.08), \mathrm{Al}(0.477)$, $\mathrm{K}(1.66), \mathrm{Zn}(0.127), \mathrm{Na}(0.123), \mathrm{Ni}(0.087), \mathrm{Co}(0.28)$ quantitatively.

The analysis revealed that Iron and Oxygen as major elements and rest of the elements are found in traces and here Sulphur is in the sulphide form. In Bharjana method of Shodhana, the percentage of Sulphur was decreased which might be due to more quantity of heat. The percentage of Oxygen has shown it as major elements which confirms that the bhasma is in oxide form. FESEM Micrographs of Swarnamakshik bhasma indicates that it belongs to the group of mineral powder. Particles of bhasma are uniformly arranged having extensively reduced grain size due to process effect, while the particles in Ashuddha Swarna makshika and Shuddha Swarrnamakshika were not uniformly arranged.The clustering nature of the bhasma was observed and it was due to the fine nature of these amorphous/ microcrystalline particles.

\section{Conclusion}

Swarnamakshika Marana was done until bhasma siddhi lakshanas were attained and it took ten putas. Study of physicochemical parameters revealed increase in percentage of iron and decrease in percentage of copper after Shodhana and subsequent Marana. The X-ray diffraction analysis showed that d-identified peaks after 10th puta Swarnamakshika bhasma composition is of Iron oxide with rhombohedral crystal system as main component. EDX analysis of Swarna makshika bhasma shows that it contains Iron and Oxygen, as major element and Copper, Sulphur, Carbon, Aluminium, Calcium etc. as minor elements. FESEM study revealed that the particle size of Ashudha and Shudha Swarnamakshika was in the range of $500 \mathrm{~nm}-3$ but after subjecting bhasma to subsequent puta s until bhasma siddhi lakshanas were attained, particle size after tenth puta was reduced to 1 which showed excellence of bhasma in regards to particle size.

\section{References}

3. Pal, Dilipkumar, Chandan Kumar Sahu, and Arindam Haldar. "Bhasma: the ancient Indian nanomedicine." Journal of advanced pharmaceutical technology \& research 5.1 (2014): 4.

4. Acharya Vagbhata. Rasa Ratna Samuchhaya with Rasaprada Hindi commentary by Dr. Indra Dev Tripathi. 2nd edition. Chaukhambha Sanskrita Bhawan; 2003.

5. 7.Shastri K, Rasatarangini of Sadanand Sharma, New delhi, Motilal Baranasi Dass, 2014, Ch. 21 , verse 7-10, Page No. 525.

6. Shastri K, Rasatarangini of Sadanand Sharma, New delhi, Motilal Baranasi Dass, 2014, Ch. 21 , verse 20, Page No. 525.

7. Sharma B.K, Instrumental method of chemical analysis, edited by Sharma M, meerut, Goel Publishing house. 2002, chapter 8, page no 252-356.

8. Tripathi, Yamini B., et al. "X-rays diffraction and microscopic analysis of tamra bhasma: An Ayurvedic metallic preparation." (2003).

9. Brunetto, R., et al. "Mid-IR, Far-IR, Raman micro-spectroscopy, and FESEM-EDX study of IDP L2021C5: Clues to its origin." Icarus 212.2 (2011): 896-910. 